\title{
CHARMS, CHANGE AND MEMORY: SOME PRINCIPLES UNDERLYING VARIATION
}

\section{Jonathan Roper}

The following paper takes as its starting point the fact that renditions of the 'same' verbal charm may differ on separate occasions. It will suggest that this phenomenon, observed especially in longer charms, arises because non-literate charmers, even when they were particularly concerned with producing a verbatim repetition of longish charms, possessed no failsafe way of telling if they had produced a verbatim repetition or not. It argues that they, especially in former non-literary times, possessed a somewhat different nonliteral sense, of what constituted the identity of a certain charm, and thus of the permissibility of variations between different performances of that 'same' charm. It reviews a series of first attempts ${ }^{1}$ to examine differences between sets of renditions; and the paper then proceeds to elucidate what principles (if any) lie behind this phenomonen and to provide names for them. But I should first like to begin with a cautionary tale.

At an early stage of my research work in the card-library of the Estonian Literary Museum, I believed I had come across just such an example of the variability of a verbal charm. A team of researchers from the Museum had recorded a snakebite charm from a woman in one region of the country in 1958, then a second team of folklorists who had been working in the same area in the following year and had recorded the 'same' charm from this woman, with several minor differences in rhythmic delivery and pronunciation, and the omission of a not-very-meaningful epithet 'hazelnut creature'. This seemed to be evidence that within the course of just a year the same charm was no longer the same charm: delivery and lexical content were variable.

It turned out however that this was an ignis fatuns summoned up by a combination of scribal idiosyncrasies, scribal error (the date 1958 was written on one card, but 1959 was written on the other), and, for my part, reader error (not heeding the presence of a particular word). These were just two transcriptions from the same fieldwork record: the same charm was the same charm. 
I retell this cautionary tale today as a reminder of an ever-present difficulty in dealing with transcriptions of oral multiforms, namely, that the differences we as researchers encounter (or invent) in these copied and recopied sources may often be non-objective differences. Such non-objective differences may arise from different practices in lineation, punctuation, the compounding of words etc., different conventions of what contextual data to surround the charm with, and sometimes from transcribing at one time in the standard form of a language, but using a more dialectal or phonetic transcription elsewhere.

Then again there are other difficulties to give us further cause for caution. For example, Mare Kõiva's (Kõiva 1995: 226) observation that

often the smallest adaptations or replacements are introduced in the text [of a healing charm] in order to adjust it to another person or disease

prompts the thought that a fieldworker is just another such person for whom verbal sequences can be changed or substituted. ${ }^{2}$

Nevertheless, thus suitably forewarned we can approach the imperfect, unstandardized transcriptions (they are, more often than not, all we have of lost oral multiforms) and compare examples of a common charm-type, to open up discussion of the process and nature of the charm transmission, ${ }^{3}$ and of what changes, if any, occur in the charms.

One series of texts have been identified which provide us with the opportunity to consider the questions of identity, variability and transmission from a sure footing. Fieldworker Albert Kruus succeeded in collecting six verbal charms from a well-known folk healer, Ell Savisikk, who lived in the central Estonia. ${ }^{4}$ That was on the 20th of June, 1925. Six years earlier a previous collector had recorded over sixty 'folksongs', some of which were in fact verbal charms, from the same folk healer.

It was fully fifty-two years after the earlier of these two periods of collection that folklorist Ellen Liiv collected a series of nearly thirty verbal charms from a woman known as Maali Sahk, who also engaged in folk-healing in the same village, and who had been Ell Savisikk's pupil. This presents us with uniquely valuable data which 
can help reveal the degree to which the same verbal charms have remained the same after a period of over half a century, and after transmission from one folk healer to another.

Unfortunately, due to the preference of the 1919 collector, when faced with the potential folkloristic riches uniquely obtainable from a living witch, for collecting folksongs, rather than verbal charms, we only have records of four charms which were recorded commonly from both Ell Savisikk and Maali Sahk. These 'same' charms show objective differences, sometimes to an especially significant degree. Elsewhere ${ }^{5}$ I have fully examined and commented on this differences. While there is not space here to go over each of these four comparative cases in very great detail, we can briefly look at some untranslated examples in this paper, before going on to attempt to suggest some wider conclusions.

Writing at the start of the century and attempting to draw conclusions as to what led to variation in folksongs, Cecil Sharp (Sharp 1907: $21 \mathrm{ff}$.) highlighted the factors of personal taste and local adaptations (i.e. ecotypification, the processes whereby adaptations are made to make the item of folklore conform to local prejudices, ecology, to feature local heroes, use local dialect etc.). While these factors certainly play their part in giving rise to variations in folksongs, and other genres as well, we can discount them here. The drive to localization will not produce markedly different results when both charmers come from the same parish, and questions of personal taste will not have such a major impact on forms of words thought of as magically endowed, as they would on words with which a singer must entertain his public. Thus the conclusions reached from comparisons made in this paper have been drawn from 'purer' material, or to put it metaphorically, this experiment was carried out in a context closer to laboratory conditions.

The layout of these charms below takes the earlier-recorded charm as the base, with the pupil's later version of the charm displayed in parallel, in such a way as to reveal the similarities and the (objective) differences between them. ${ }^{6}$ So, amongst various other conventions, when either version contains lines that the other one lacks then the corresponding space in the opposite text is left blank. And when the later (that is the right-hand side) text differs objectively 
from the earlier (left-hand) text, then the words or entire line(s) of the later text are italicised.

The first set of charm-variants are quite similar:

E 56373 (2)

from Ell Savisikk in 1925
RKM II 289, 470 (31)

from Maali Sahk in 1971

Nõidumese tagasisaatmise laul Tagasi saatmise sõnad

1 Urjuh, unti, tohoh, tonti,

2 Vastutan teid nüüd tagasi.

3 Pööra ümmer ühessä korda, Pööra ümber üheksa korda 1

4 Karga tagasi kahessa korda, Karga tagasi kaheksa korda 2

5 Seitse korda selgemini,

6 Kuus korda kurjemini,

7 Viis korda vihasemini, Seitse korda selgemini 3

8 Neli kord neljä kõvasti Kuus korda kurjemini

Viis korda vihasemini 4

9 Oma äti aeda juure,

10 Oma taadi tanavisse

Neli korda neela kõvasti

5

Oma äti aedo juurde 6

Oma taadi tänavisse

Käi läbi karjalaudad

Siblitse sigade laudad

7

11 Käi läbi karjalaadad

12 Lendä läbi lehmälaadad

13 Tammu läbi tallelaadad,

14 Siält sa poe pööningule,

15 Siält sa tambitare piäle, 16 Siält sa karga kamripiäle,

17 Siält sa lase laole,

18 Vajo varsade künässe,

19 Peri siis siält peremiist,

20 Taga nõua taadikest,

21 Kuse siis tal kulbi sisse.

22 Situ siidilina sisse.

23 Rist olgu sellele, kis

24 On risti saatnud, olgo

25 Isäne ja emäne.

Tammu läbi tallelaudad

Sealt sa poe pööningule $\quad 12$

Sealt sa tambitare peale $\quad 13$

Sealt siis lase laole $\quad 14$

Vaju varssade künasse. $\quad 15$

Peri sealt siis peremeest taga 16

Nõua oma taadikest $\quad 17$

Kuse siis tal kulbi sisse. $\quad 18$

Situ siidilina sisse. $\quad 19$

Rist olgu sellele, kes on $\quad 20$

Risti saatnud, olgu $t a$ isane 21

$v \tilde{o} i$ emane.

22

These are numeric charms used to send back the effects of witchcraft. As you can see the small amount of italicized text (showing differences) and of white spaces (denoting lines which have nothing corresponding to them), means that these two variants though 
they were recorded forty-seven years apart from two different healers are, objectively speaking, largely identical.

It is the earlier of the two which is the longer version, thanks largely to a two-line introduction absent from the pupil's variant. Various minor differences exist within commonly-featured lines, ${ }^{7}$ but more interestingly than these low-level differences, we can see that there are five blank lines on the lay-out, showing us that there are four lines which appear only in Savisikk's earlier version, and one which is unique to the pupil's later version. ${ }^{8}$

The most noticeable difference between these two variants is the absence of the introductory formulæ (lines $\mathbf{1}$ and $\mathbf{2}$ ) in the pupil's text; ${ }^{9}$ its absence shows the dropping of a self-contained part, or a 'section', as a whole from the charm. Though, strictly speaking, it was an 'unnecessary' section (the spell still works, one must presume, without it), this would seem to diminish the incantatory force of the charm.

Moving down, the absence of lines $\mathbf{1 2}$ and $\mathbf{1 6}$ from Sahk's version seems to be explicable is that if any lines in a series of lines are to be forgotten, they are most likely to be the ones nearer to the end of a list than at the beginning. Therefore these two lines, representing penultimate members of series (formed by 11-13 and 1417 in Sakh's version) are among those most likely to be forgotten.

But the most interesting discrepancy is that there is one line in the later version not present in the earlier version. This can be taken as a signal that what we are not dealing with here is not simply a case of decay, due to failing memory: it is a sign that this tradition was not purely memorial. ${ }^{10}$

Another pair is a set of snake-adjuration charms:

E $56372(1)$

from Ell Savisikk in 1925

Ussi sõnad

1 Madu sanni, marja sanni,

2 Kulu sanni, kulda sanni,

3 Lehe karva, lille karva,

4 õle karva, eenä karva,
RKM II 289, 452 (7)

from Maali Sahk in 1971

Tiirutele sööja ussi

Madu sanni, marja sanni, 1

Kulu sanni, kulda sanni, $\quad 2$

Hele karva, heina karva, 3

Lehe karva, lille karva, ${ }^{*} 4$ 
5 Soo karva, sinepi karva,

6 Vee karva, virtsa karva,

Tuha karva, tuki karva,

7 Alli ussi aava karva,

Vee karva, virtsa karva,

8 Salepu sarapu karva,

9 Vaski ussi mu vaderi,

Halli ussi haava karva,

Vaskussi muu vaderi, $\quad 8$

10 Vesi ussi vennapoega,

11 Savi ussi saksapoega,

Vaskuss mu vennapoega,

8
9

12 Usi aia alune,

13 Salepu soo-alune,

14 Madalu maa-alune,

15 ära mind salaja salva,

16 Nägemätä näpistä.

Tera ussi, poosa ussi,

ära mind salaja salva, $\quad 11$

$17 \mathrm{Mul}$ on juures jumala rohud,

$18 \mathrm{Mul}$ on külles küisilauku,

Nagemata näpista.

Mul [] juures jumala rohud, 13

$19 \mathrm{Mul}$ on manu maarja eenäd.

Mul juures küüslaugu kü̈̈ned, 14

Manner marjaheinad.

15

20 Luu karva, lume karva,

21 Ele eenä karvalane,

22 Maa karva, muti karva,

23 Mine näri käsipuud,

24 Mine ammusta aavapuud,

25 ära ime ihu, ära luutsuta luud,

26 Kadugu uss, kadagu

27 Kõik aigus maa alla, mätta alla.

*Note: lines 3-4 of Savisikk's charm appear transposed in Sahk's variant.

We can see that the most striking objective difference is the reduced length of the pupil's later version. Lines 1-16 in the first and 1-12 in the second both make up a single sentence which begins with a long invocation-cum-names-section which is capped by the identical adjuration in 15-16 and 11-12 respectively: "ära mind salaja salva,/ Nägemätä näpistä” ('don't sting me secretly,/ don't nip me, unseen'), but the pupil's later names-section is fully four verse-lines shorter. This reduction is a result of failure to preserve or to replace the second half of Ell Savisikk's corresponding section of text. 
As regards the four nominal-series in Ell Savisikk's first fourteen lines we can very clearly see the progressive falling-off in the accuracy of the pupil's corresponding series: the first, the sanni-series, is replicated exactly, the second, the karva-series, is broadly the same, though with one transposition, one subsititution and one omission, the third, ussi-series, has no exact replications, but has instead one minor variation, one example of interference and one omission; while the fourth, the alune-series, has no analogue whatsoever. This pattern of decline is also to be seen within the series: though they begin fairly faithfully, it is the final verse line that is lost in the pupil's versions of the karva-series and the ussi-series. Thus for this major section of the charm we can see that the greatest replication occurs at the start and the end, with the first two and last two lines of each version being exactly the same, but that between these important positions verbatim reproduction steadily decreases.

Another one of the four sets of common charms were also for adjuring snakes:11

E $51453(54)$

from Ell Savisikk in 1919

Ussi sõnad
RKM II 289, 471 (33)

from Maali Sahk in 1971

Ussi sõnad

1 Kis sind saadis sündimasta Kesse sundis sündima

2 Konnasta kohuta mõist

3 Pahast vaemust vaevatud

4 Maakarva mutikarva

5 Pajokarva patikarva

6 Elekarva einakarva

7 Valekarva vasekarva

8 Alli ussi, aavakarva

9 Vesi ussi vennapoega

10 Savi ussi saksapeoga
$\{2$ corresponds with line 5 below

Pahast vaimust valetatud 2

Käharpea kivialune

Käharpea künkaalune

Konnadega kohut mõistnud. $\quad 5$

Maa karva muti karva $\quad 6$

Paju karva pati karva $\quad 7$

Rohu karva rooste karva 8

Soo karva savi karva $\quad 9$

Hele[] heinakarvaline $\quad 10$ 
11 Ussi aia alla

Soo sammalde segaja $\quad 11$

Läbi põõsaste pugeja $\quad 12$

Ussukene, sussikene $\quad 13$

23 ära sa mind salaja salva ära [] mind salaja salva 14

24 Nägemata näpista Nägemata näpista 15

Mul on küljes kü̈slaugud 16

$25 \mathrm{Mul}$ juures jumala rohod Mul on juures juudirohud 17

$26 \mathrm{Mul}$ on maarus maarja eenad.

Here the situation is reversed: it is the pupil's later version which is objectively the longer; the seemingly greater length of Savisikk's original version is entirely due to the fact that lines 12-22 of it are an exact repetition of its lines 1-11. It is in the pupil's later variant that we find the greatest number of different lines, excluding repetitions, Savisikk's version possesses eleven verse-lines, the pupil's thirteen; they have six more-or-less similar lines in common. This leaves us for the first time with an interesting case in which the version recorded later has a greater amount of unrepeated material. Not only that, but the later-recorded version has more lines without analogues from the earlier charm, than it does with analogues.

Here, as in other examples, the greatest mutual consistency occurs at the start: the first six lines of Savisikk's charm all have analogic lines in the pupil's version, the next five lines of Savisikk's charm all lack analogues.

Next, in lines 4-11, comes a tight-knit names-cum-origins section made up of eight lines (which, when considered alongside the fourline closing section of this charm, suggests that the organizing number in her rendition is four.) The pupil's equivalent of this section (which also consists of eight lines) shares with Savisikk's version only two of its lines (the first two, of course). Though these sections feature a different range of epithets for the snake, they are all clearly selected from the same tradition (they all insult and belittle the snake), and certainly they are selected from overlapping epithet-repertoires too. Perhaps the most interesting point of similarity is structural, rather than surface, namely that both these eight-line sections begin by deployment of the longer series, 
then with a less long series, and then conclude with either the shortest series or a line not fully in series.

The concluding four lines of each of these charms hark back strongly to the pre-concluding and concluding lines in the other type of snake charm these women both knew. The penultimate pairs of lines, 2324 and 14-15, are almost exactly the same as lines in that other snake charm. ${ }^{12}$ And the last two lines of Ell Savisikk's charm feature slightly different versions of lines from what we might call her repertoire of threats beginning "Mul on ..." ('I have'), than we came across in the other type of snake adjuration charm above. Ell Savisikk had, we know, at least one other of this kind of lines in her repertoire. The reason for not deploying it here is surely so as to be in keeping with the charm's organizing number, its 'four-ness'.

Similarly, the pupil uses only two of her stock of this type of line,$^{13}$ again presumably to be in accord with the charm's organizing number.

After this brief look at some concrete examples, we can now remark on some of the conclusions which it was possible to draw about the nature of the performance of charms in this tradition, observations derived from a much fuller comparison of the four sets of charms.

It seems clear that we should first of all note that this performance tradition is memorial ${ }^{14}$ (as shown by the presence of lines in the earlier text, and the presence of them or lines similar to them in the later charm. ${ }^{15}$ However this performance tradition is also improvisatory (as demonstrated by the presence of lines in the later texts absent from the earlier texts). ${ }^{16}$ The charm is held in the performer's memory not as a mere string of words but, at some level, as an arc, the shape traced in the realization of a collection of verse-lines organised into a hierarchy of structured units: the whole, parts, sections, subsections, lines, phrases, words. The most notable of these units are sections ${ }^{\mathbf{1 7}}$ with their own particular drifts, and their own typical syntactic template(s), (one argument for this is that sections are sometimes dropped as a whole). When these sequences of repeated syntactic templates repeatedly feature not merely the same specified part of speech (e.g. a certain position always contains some adjective or other), but actually re- 
peat particular words, then we can speak of the occurrence of series of variable formulæ, i.e. lines with fixed elements, in addition to substitutable positions, or metrical slots, in which alternative nouns, adjectives and verbs can be inserted. Lower order items in the hierarchy of units include subsections and individual lines. Higher order units, including the critical division of a charm into two major units, or parts ${ }^{18}$ consisting of several sections taken together. This hierarchy of related units (the whole charm, the two parts, the sections, the subsections, lines, phrases, words, as shown in the diagram) gives the charms a continuity that a merely random sequence of verbal building blocks, all of the same size and weight, could never possess.

Figure 1.

whole of charm

part of charm

sections

subsections

lines

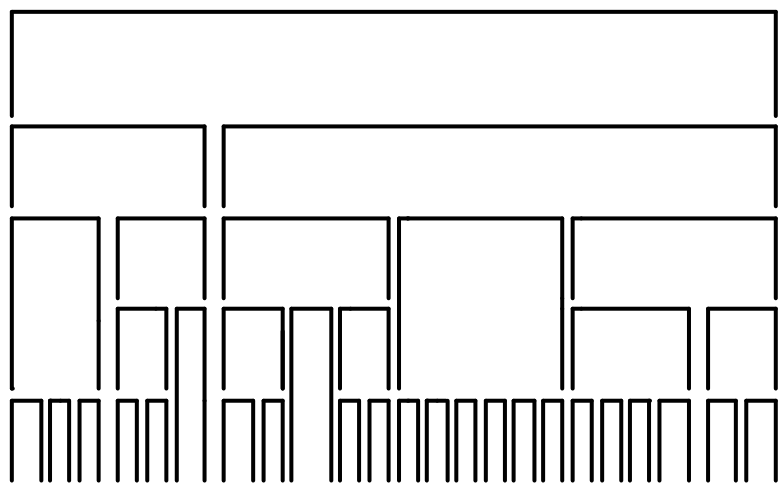

Sections, although they often have their own internal shifts, subsections and climaxes, are not merely coherent internally; following the overall logic of the charm, they lead on externally to one another. This gives the charm as a whole its arc, something which is analogous to the shape of a story's narrative (or 'sjužet', in formalist terminology), which remains constant through various tellings of the same tale. Indeed, it is also similar to what when discussing sections can, as we have done, be termed their 'drift', a section's drift can also be realized in differing ways in different renditions. The arc of a particular charm is what is being traced or followed throughout whatever differing realizations of sections (or 
even omissions of them) are involved in any particular rendition, and it is by their arcs that we can identify different charms as being members of the same charm-type.

As regards the realization of sections, in the examples mentioned above memorial accuracy is highest at the start of sections and of subsections, it goes on to decline steadily during the middle, and it is worst at the end; this is especially true for catalogues, which are in effect lists with no narrative glue to hold them together. Series of parellelisms ('Parallelstellen') tend to show high redundancy, and while such redundant lines may be valued for their incantatory force and thus be retained or even expanded upon, redundant parallelisms do, of all lines, tend to be the first candidates for omission. The influence of organizing numbers, i.e. the number of members deemed fit to constitute a catalogue, and the total number of lines deemed fit to form a (sub)section, can be decisive in such considerations of expansion and omission. An exception to this general rule is that memorial accuracy is sometimes extremely high right at the end of a section (for example the last two lines), if it acts as a cap to a section and has a fresh syntactic structure. Lines which are not (correctly or partially) remembered, may be dropped altogether, may undergo interference from the preceding syntactic frames, or may be replaced by 'improvised' lines if the performer feels something is lacking. These improvisations will tend to fit the preceding syntactic templates and will make use of traditionally-appropriate diction. Sometimes performers may draw on their repertoire of lines, which has been built up by hearing various charms, or indeed other similar forms of traditional verse, throughout their lifetimes. Some lines are of course common to a variety of charm-types. Relevant repertoires in this tradition include for example epithet-repertoires, and adjuration-repertoires. These repertoires can vary greatly in size; for example, a charmer could know half-a-dozen charms and two dozen epithets, but have only one adjuration in her or his repertoire. Phonetic features, particularly such as initial consonants in this tradition of alliterative verse, and in other traditions end-rhyme, may well influence the choice of newly improvised words, without the performer necessarily being consciously aware of this. In metrical traditions, metre and a stronger sense of what is acceptable as a line will be influential on the form of improvised lines. ${ }^{19}$ Such sound patterns, along 
with syntactic patterns (including anaphora and formulæ), organizing numbers and metrical form are all influential upon the realization of charms in two seemingly opposed ways: they can function as a mnemonic, and thus maintain the charm as it has previously been performed, and, equally, by the felt presence of their demands, they can bring about tradition-abiding innovations. For a charmer, having a feel for a particular charm-tradition (as opposed to just knowing a charm or two) is a matter of feeling and meeting these demands while in performance (regardless of how explicitly conscious she or he is of them).

The common folkloristic processes of regularization via erosion and sedimentation whereby a charm becomes traditionsmoothed will always be active, as examples of a natural form of entropy, whatever the state of health of a charm-tradition. However, if a tradition is dying, then, usually, renditions by an earlier charmer will be fuller than those of that charmer's successor(s), although some parts of some of a later charmer's renditions may preserve features the earlier charmer only sometimes used, but which were perhaps left out on the one occasion a folklorist came round to record them. Overall, although there may be some natural developments and variations, charms will tend to become more and more reduced and folklorists will be tempted to use the word "decay" to describe this steady approach to zero. However, when a tradition is flourishing, i.e. when repertoires of charms and lines from charms are full, and there is a fairly regular call for a charmer to practice, then overall there is no decay, only natural variation, and charms may shrink, keep a similar length, or grow longer, as the next generation of charmers takes them on as their own. In a flourishing tradition decay, growth and constancy will all take place at the same time.

I believe these conclusions will be borne out and expanded on by researchers of both Estonian and other traditions of verse-charms who repeat similar research into the variations a charmer and her or his pupil make in their renditions of verse-charms, ${ }^{20}$ and also in a field not examined in the present study but in need of study, the differences a single charmer makes in her or his own performances of particular charm-types throughout her or his lifetime. ${ }^{21}$ 


\title{
Summary of Principles Underlying Variation in Improvisatory-Memorial Performance Traditions
}

\author{
sound patterns \\ syntactic templates all have both innovative and memorial \\ influence \\ organizing numbers \\ metrical form \\ interference only has an innovatory effect
}

In such traditions, the charm is held in the performer's memory not as (or not only as) a mere string of words but, at some level, as a hierarchical form made up of parts, which consists of sections, made up of subsections, consisting of lines, made up of phrases, which are made out of words (see diagram overleaf).

In performances the charmer traces the arc of the charm, remembering and improvising as fitting.

In rendering sections the charm follows through the (semantic) drift of that section filling out that section's own typical syntactic template(s) in various realizations often drawing upon their repertoires of, for example, epithet-repertoires, adjuration-repertoires, threat-repertoires etc.

\section{Comments}

1 This paper has benefitted from consideration of remarks relating to transmission and performance of oral multiforms made in passing in Kiparsky (1976), especially pp. 95-98, Kerewsky-Halpern and Foley (1978), especially pp. 909-920, and Foley (1995), especially pp. 115-135. However, none of these authors attempted to abstract from their discussions what general principles were at work in the mind of the charmer or singer and stood behind the variations in their renditions. Sadly, as Foley (1995: 125) admitted "a thoroughgoing philological explanation of the traditional rules underlying the charm register is beyond the scope of the present exposition."

${ }^{2}$ Indeed, perhaps we should conclude that it is precisely for such literate, high-status outsiders, an unusual audience in an unusual 
situation, paying close heed to every detail of a charm rendition, marking the charmer's exact words down in their notebooks or by tape-recording them, that a charm is most likely to be unnaturally mutated. A situation may become highly unusual when, for example, a fieldworker may ask for the performance of a healing charm for their records, in the absence of anyone needing to be healed. Lennart Meri (public discussion, 1994) once related the tale of how when he and his film crew had finally arrived at a remote Siberian settlement to film a Nganassan shaman perform his rites, they were surprised and had no answer prepared when the shaman asked for details of what particular future event they wanted to be foretold: they had just vaguely assumed that he would 'perform', without doing any particular supernatural task, without fulfilling any specific function.

${ }^{4}$ These investigations touch on questions of how verbal charms are passed on down the generations, whether by oral transmission (or indeed by oral-and-written transmission A charm may be said to have passed from one charmer to another by means of oraland-written transmission when, for example, the recipient of the charm has had a copy of the charm on paper from which they have memorized the words. In recent times much transmission has involved such methods and a term such as 'oral-and-written transmission' is a more accurate description of this process than an absolutist use of 'oral transmission'. A clear example of this can be found in Kõiva (1995: 226) where a healer, Aino Teppan, from Maarja Magdaleena, near Tartu, and the book of incantations left her by her mother-in-law are being discussed: "According to her own words, A. Teppan uses these written notes to refresh her memory, just like her mother-in-law used to do."

${ }^{4}$ She lived in fact in the village of Leie in the parish of Kolga Jaani and was also known as Serva Ell.

${ }^{5}$ In Chapter Four of my M.A. thesis (Roper 1997).

${ }^{6}$ All the non-objective differences of spelling, punctuation, lineation, and the purely dialectal differences (e.g. 'õle' for 'hele') were not marked, the differences in capitalisation were silently regularised; differences in compounding were similarily ignored, except 
where they involve a variation in the number of syllables. Absent words are indicated by italic square brackets, thus [ ]. Words and word-endings absent in the Estonian originals, but semantically present and needed in an English rendering of the texts will appear between square brackets, thus [ ]. Features in lines common to both versions that only appear in the later variant are marked by the underline, thus_. Differences in the titles these women gave to the folklorists for these charms are not marked. Problems of how to represent charms with internal repetition were dealt with on a case-by-case basis, and were discussed in the respective commentaries. In some cases notes were included to show where lines are simply transposed.

${ }^{7}$ For example, the differences between lines 17 and 14, "siis" ('then'), for "sa", "you', and $\mathbf{1 9}$ and 16, the inversion of "siis siält" (then from there') as "sealt siis" ('from there then'). The most noteworthy point about these minor differences is the preservation of the alliterative theme of each line, despite the minor discrepancies of meaning. ${ }^{8}$ Excluding the omission of the introduction in the later version, the three other unique lines come at the middle or end of series.

${ }^{9}$ Viz. "Urjuh, unti, tohoh, tonti,/ Vastutan teid nüüd tagasi." ('Urjuh, Wolf, Tohoh, Spectre,/ I'm now sending you back'; "Urjuh" and "tohoh" were cries used, for example, when hunting.

${ }^{10}$ Alternatives to this supposition include the possibilities a) that this line could have originally been in the version Savisikk taught to Sahk and missing in the version Savisikk told the collector, or b) that the line may have been remebered from the general repertoire of such lines Maali Sahk possessed (she knew at least two snake-adjuration charms, for example, which, as will be shown below, shared access to a common hoard of lines).

11 The overall structure of this charm is rather similar to that of the previous snake adjuration charms: a question preceding an extensive names-section is capped by a two-line adjuration (exactly the same adjurations as in the variants of the previous charm-type). The charms both conclude with a two-line catalogue of the healer's resources (which are also similar to those we have seen before). 
12 These lines are almost exactly the same as lines 15-16 and 1112 in the other charm, the exception is the surprising use of pleonastic "sa" ('you') here by Ell Savisikk.

${ }^{13}$ Although only two fully-fledged lines beginning 'Mul on ...' appear in the pupil's first snake charm, it would seem that the metrically deficient line 15 of that charm, "Manner marjaheinad", is an incomplete attempt at *Mul on manner marjaheinad", an analogue to which appears in the corresponding position in Ell Savisikk's charm.

${ }^{14}$ Memorial reproduction is, no doubt, higher in such genres as charms, than it is in those oral genres more intended as entertainment. Those entertaining genres, such as verse-tales, no doubt feature more improvisations. As Kiparsky (1976: 95-96) explains, genres associated with ritual or the imparting of mythic knowledge tend to higher stability, than genres in which entertainment is the goal.

${ }^{15}$ Indeed the occasional absence of such lines in the later texts also supports this, as it is an example of failed memory.

${ }^{16}$ Compare Lord (1987: 336): “[when lines] are not always repeated, whether in the same position or not, or in the same form, [it] is precisely because they were not memorized."

${ }^{17}$ Foley (1995) uses the idea of 'frames' as the basis concept in his analysis of Serbian charms, which superficially would seem synonymous with the concept of 'sections' used here. These two concepts differ however in that sections are made up of lines with a shared drift and thus are identifiable on the basis of function, while Foley's 'frames', on the other hand, consist of lines with a shared motif, and thus are a concept dealing with surface detail. For example, Foley in his earlier analysis (Kerewsky-Halpern \& Foley 1978: 909) divided a single orgins section into two frames because the series of irreal locations which were based on animal motifs, shifted to featuring religious motifs, even though the series of lines involved all had the same drift and syntactic patterning, and were performing the same function within the charm. In our terminology these would be subsections. 
${ }^{18}$ Various critics, such as Conrad (1989), and others, see charms as possessing a fundamentally bipartite structure, first, statement of problem, then, remedy. Likewise, Weston (1985) sees charms as possessing a basic structure of a) gathering or evoking of power, and b) chanelling and discharging that power. This is in turn reminiscent of Greene's (1993) analysis of invocations, both in poetry and in charms, into a first part of naming someone or something absent, and a second part of summoning them to appear and/or do something. This is itself reminiscent of our contemporary health service with its bipartite mode of operation: first diagnosis, then referral for treatment.

19 The poor sense of what constitutes a metrically-acceptable line evident in some of The pupil's renditions is perfectly explicable when we realize that the tradition of verse in Kalevala metre (or 'regi'type verse) is extinct among 'the folk'. Kalevala metre was being strongly challenged in Estonia by rhymed verse typical of literary productions and church hymns in the seventeenth- and eighteenthcenturies. Composition of fresh verse in this metre finally petered out in Estonia in the first quarter of the nineteenth-century (Mare Kõiva, personal communication, 1997). Following this disappearance of active knowledge of the metre (the knowledge of how compose in it), passive knowledge (the knowledge of how to parse according to it) was also bound to decline. If we had been able by some miracle to have recorded texts by a witch and her pupil in, for example, the sixteenth century, we presumably would not have encountered unmetrical lines (or to put it another way 'non-lines') in the pupil's renditions. The decline of metrical awareness may be a factor which increases the amount of variation from one generation to the next. Some prose charms I have examined elsewhere certainly had a much greater variability in their prose historiolas.

${ }^{20}$ For example, the existence of three variants of the same charm, collected within a six year span of one another in the same subdivision or ward (Kaisma vald) of the same parish (Pärnu-Jaagupi kihelkond) in the west of Estonia, seems to be another potentially valuable case. The three charms under discussion here are

ERA II 211 342/3 (VII), collected from Riina Peterkopf in 1939, when she was 89 years old; 
E 82644 (2), collected from Anna Tompson in 1933, when she was 52 years old,

and E 82640/1 (1), collected from Mari Koch in 1933, when she was 86 years old.

All the examples are of the same subtype of the Second Merseburg charm (sub-type (e) 'Woman, cast a spell'), and all consist of a prose historiola featuring Jesus who commands a woman to heal a sprain, which she does not know how to do, whereupon he teaches her the more-or-less metrical healing formulæ. That there must be some complex transmissory relationship between at least two of the texts we have is virtually guaranteed by the fact that Church records (the 'Kaisma vallaarhiiv', now held at the Estonian Historical Archives in Tartu, fond 4706 nim 1, s10, and fond 1865 nim 3 s194:3) show that Mari Koch and Riina Peterkopf, were both the daughters of Peeter (in the records the name is abbrievated 'Peth.') and Ann Weber.

Looking at the objective differences between the three charms, we can see that though they are similar enough to be designated members of the same sub-type, they have their points of divergence: the presence or absence in them of a ratification and of the character Mary, and the length of their magical formulæ. In fact it is possible to find that whichever two of these three charms we pick out for comparison they both of them will show elements of similarity, missing from the third charm, both in their historiolas and in their magical formulæ. What is a researcher to make of this?

I would suggest that what can be made of this is a realisation about the variable nature of such 'oral texts'. In the forms as we have them, it is evident that both of the older women's charms contain elements found in the supposed offspring-charm. Maybe, then, both of them are in a parental relationship to the younger woman's charm. As the two older women were sisters it would not have been at all difficult for Anna Tompson the youngest of these three women, to have been taught, or to have picked up such the elements of such a repertoire from witnessing charm-rituals as a child performed by these two old women (quite possibly her relations). When people have themselves heard several versions of the 'same' charm, then they have a stock of variant phrases and features they can 
draw upon for their own performances of this charm, and this is a documented means of charm transmission: for examples, see Kõiva (1990: 186-191). Perhaps this is where an otherwise inexplicable 'asemele' at the end ofAnna Tompson's version of the magic formulæ originates, and in tagging on this word after the standard lines she was indicating that she knew (through previous reading or hearing) of an alternative way of constructing those formulæ.

The likelihood of hearing several versions of the same charm must have been all the greater in the days of greater reliance upon folkhealing, and less comprehensive literacy, when the charm-tradition was stronger. This would allow us to conceive of (a degree of) variation being part of the nature of longer charms in that tradition, rather than lamely supposing variation to be a product purely of loose transmission, failing memory or a once-and-for-all decision of a younger charmer to reject or adopt features present in an older charmer's performance. And indeed there is no reason not to suppose that the older women's renditions were not themselves variable their versions of this charm-type were not always the identical: it may well have been the case, that their performances of the words of this charm varied, though staying within the bounds of a primarily memorial (rather than an improvisatory) tradition.

${ }^{21}$ In verse-charm traditions which are strophic and end-rhymed (such as the modern English generally is, with its propensity for quatrains and couplets), the scope for major improvisatory variation will presumably tend not to be so great. Compare Buchan (1972: 147) "the stanza provides an aural pattern rarely present in the Eastern European songs studied by Lord, the pattern of rhyme. This pattern exerts a powerful and compelling influence on the making of the texts."

\section{References cited}

Buchan, D. 1972. The Ballad and the Folk. London.

Conrad, J. L. 1989. Russian Ritual Incantations: Tradition, Diversity and Continuity. Slavic and East European Journal, Vol. 33, No. 3.

Foley, J. 1995. The Singer of Tales in Performance. Bloomington.

Greene, T. M. 1993. Poetry as Invocation. New Literary Review, Vol. 24, pp. 495-517. 
Kerewsky-Halpern, B. \& Foley, J. 1978. The Power of the Word Healing Charms as an Oral Genre. Journal of American Folklore, Vol. 91, pp. 903-924.

Kiparsky, P. 1976. Oral Poetry: Some Linguistic and Typological Considerations. Oral Literature and the Formula, pp. 73-106. Edited by Stolz, B. \& Shannon, R. Ann Arbor.

Kõiva, M. 1990. Estonskie zagovory - klassifikatsia $i$ ganrovye osobennosti. Tallinn: unpublished dissertation. [Estonian charms classification and generic characteristics.]

Kõiva, M. 1995. From Incantations to Rites. Folk Belief Today. Edited by Mare Kõiva \& Kai Vassiljeva.Tartu.

Lord, A. B. 1987. The Nature of Oral Poetry. Comparative Research on Oral Traditions. Ed. by J. Foley. Columbus.

Roper, J. 1997. Traditional Verbal Charms, with particular reference to the Estonian and English charm-traditions. University of Sheffield M. A. thesis.

Sharp, C. 1907. English Folk Song: Some Conclusions. London.

Weston. L. M. C. 1985. The Language of Magic in Two Old English Metrical Charms. Neuphilologische Mitteilungen, Vol.86, No. 6, pp. 176-186.

\section{References used}

Conrad, J. L. 1983. Magic Charms and Healing Rituals in Contemporary Yugoslavia. Southeastern Europe, Vol. 10, No. 2, pp. 422-444.

Kõiva, M. 1996. The Transmission of Knowledge among Estonian witch-doctors. Electronic Journal of Folklore, Vol. 2, pp. 41-72.

Lord, A. B. 1960. The Singer of Tales. London.

Lord, A. B. 1995. The Singer Resumes the Tale. Ed. by M. L. L. Lord. London.

Rubin, D. C. 1995. Memory in Oral Traditions: the Cognitive Psychology of Epic, Ballads and Counting Out Rhymes. Oxford. 